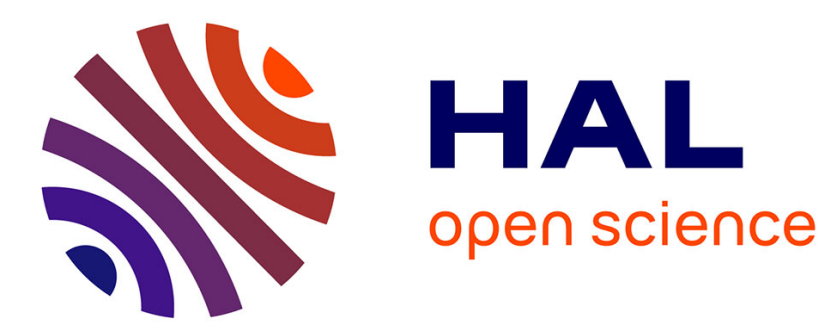

\title{
Jews and Muslims in France: Changing responses to cultural and religious diversity \\ Martine Cohen
}

\section{To cite this version:}

Martine Cohen. Jews and Muslims in France: Changing responses to cultural and religious diversity. 2008. halshs-00276211

\author{
HAL Id: halshs-00276211 \\ https://shs.hal.science/halshs-00276211 \\ Preprint submitted on 28 Apr 2008
}

HAL is a multi-disciplinary open access archive for the deposit and dissemination of scientific research documents, whether they are published or not. The documents may come from teaching and research institutions in France or abroad, or from public or private research centers.
L'archive ouverte pluridisciplinaire HAL, est destinée au dépôt et à la diffusion de documents scientifiques de niveau recherche, publiés ou non, émanant des établissements d'enseignement et de recherche français ou étrangers, des laboratoires publics ou privés. 


\section{"Jews and Muslims in France: \\ Changing responses to cultural and religious diversity"}

Martine Cohen

\section{Introduction}

Over the last few decades, Western European societies have been facing a newly reinforced pluralism, due to the massive presence of Muslims and, more generally, to a broader process of globalization. This situation calls into question their national identity, which was supposed until then to foster a neutral liberal State.

In France, after a period of openness to cultural diversity (in the 1970's and the 1980's), a new social debate has emerged on the subject of "secularism", which has been oscillating between two extreme positions. On one hand, a strict secularism maintains religious identities in the private sphere, helping to preserve individual freedom and civil society as a whole from religious groups' pressure; this position is identified by its adherents as the "true" secularism, the uniqueness of which is strongly correlated with France and the term "laïcite". On the other hand, secularism affords a more prominent place in the public sphere to religious identities, allowing them to participate in public moral issues; this position is also referred to as French "laïcité" but rather highlights its historical liberal trend toward religion - all the more as its contemporary evolution makes possible to relate it to other forms of associative and cultural engagement. In this case, laïcité is often associated with multiculturalism.

I propose to analyse the national and international factors of this growing debate on secularism, expressed here as "laïcité $v s$ multiculturalism" - although I know this formulation tends to adopt the first position on the "uniqueness" of "French laïcite" against "Anglo-Saxon multiculturalism". I will first highlight, in a short historical overview, the background of this debate with discussion of the respective positions of Jews and Muslims in France before World War II. In conclusion, I will ask the question: how do multiculturalism and globalization destabilize secularization processes in "old" national identities? 


\section{Jews and Muslims in France before World War II : a limited religious pluralism}

A legal framework for religious pluralism was set up in the nineteenth century France, more precisely during the Restoration period (1814-1830). But this pluralistic framework, which included Protestants and Jews in the French dominant Catholic society by offering them equal rights, showed some limitations, either on the legal level or on the factual level. It was a limited religious pluralism.

For Jews, a full legal equality was not achieved before the middle of the nineteenth century. Among the examples of this long-lasting legal process, it must be noted that a Napoleonic discriminatory decree was taken in 1808 against Jews (actually, only Alsacian Jews were concerned, but they were the vast majority of them); this so-called "loathsome decree" was revoked only in 1818. Furthermore, rabbis were paid by the State (like others clerics) only in 1831, and a selective courtroom oath was required from Jews until 1846.

Under the Second Empire and the Third Republic, Jews went through a process of socio-economic betterment and gained access to civil positions in the Army, the Judiciary and Governmental positions. But continuing social discriminations lasted until the end of the nineteenth century, and two major shocks called into question Jewish social integration: the Dreyfus Affair (1894-1906) and, even more so, the Vichy regime ${ }^{1}$.

The Dreyfus Affair occurred at a moment of fragility for the Republic. Anti-Semitism gathered together anti-modernist Catholics, anti-Germans Patriots (especially in the Army) and anti-Capitalist left movements. The ideological battle turned out into an opposition between two conceptions of French identity; a monolithic vision of a Catholic France - which evidently excluded the Jews - or a Republican regime. Fortunately for the Jews, supported by a new group of "Intellectuals" (among them the writer Emile Zola, the sociologist Emile

\footnotetext{
${ }^{1}$ For a history of French Jewry in the nineteenth and early twentieth centuries, see: Albert-Cohen (1977), Berkowitz (1989), Graetz (1996), Hyman (1998), Malinovich (2008), Hermon-Belot (1999).
} 
Durkheim, the French-Jewish Anarchist Bernard Lazare), the ideals of justice and equality overcame the "ethnic" conception of French identity. This victory led Jews to a reinforced adhesion to the Republic. They continued to be involved in the building of a strong centralised State, whose authority was supposed to protect them from the forces of AntiSemitism $^{2}$. Jews benefited from the Law of Separation between Church and State (1905), which removed the legal monopoly of the Consistory and allowed the creation of an independent Reform congregation, founded by open-minded intellectuals who aspired to counter assimilation ${ }^{3}$. Moreover, a cultural Jewish revival sprang up in the 1920's, which shaped a new sense of Jewish pride among the intellectuals and the associative realms. But Anti-Semitism flourished again a few years later, in the context of economic crisis, and the Vichy Regime which ruled France under the Nazi occupation, succeeded in legally expelling Jews from the national frame for four long years. Opposing the principle of pluralism, the Vichy crisis showed the continuing marks of a racial-Catholic conception of French identity. For a second time, Republican values were at stake; and fortunately again, Jews found common interest with the French Resistance, as well as with the numerous French non-Jews who helped them to escape from deportation. The final victory over Nazism and the Vichy Regime allowed Jews to re-integrate France on the basis of these Republican values. Thirty years later, facing the upsurge of a renewed Anti-Semitism and the trials of personalities who were involved at a high level of the Vichy Regime, they will break the silence ${ }^{4}$.

As for Muslims, it is in Colonial Algeria that their unequal condition was evident, as contrasted with the legal status of the Jews. After the incorporation of Algeria into the French

\footnotetext{
${ }^{2}$ See Birnbaum (1992).

${ }^{3}$ More generally, the Law of Separation erased the unequal status between "recognized" and non-recognized religions (essentially small Protestant groups), creating a newly pluralistic situation.

${ }^{4}$ In the 1970 's, the memory of this dramatic period will support a new Jewish activism, first condemning France in general for its Anti-Semitism, and then requiring to take into account this moral condemnation within the national memory of France.
} 
State (three French departments were constituted in 1858), Algerian Jews, but not Muslims, were offered full citizenship by the "Crémieux Decree" (1870). This exclusion of Muslims contradicted the principle of religious pluralism, and as it is well known, even if Muslims converted to Catholicism, they maintained inferior "subjects" rather than full French citizens. If the majority of the Algerian Jews accepted their distinction from the other "indigènes", it was not without ambivalence. They indeed cherished their new enfranchisement from a "dhimmi"/protected condition, but they continued to feel close to Muslims by their strong communitarian religiosity. Besides, with the further reinforcement of a local European AntiSemitism - during the Dreyfus Affair and the Vichy Regime ${ }^{5}$ - Jews could have common interests with Muslims and a majority of them were indeed close to left Republican parties. However, only a few fought openly for equal rights for Muslims ${ }^{6}$. Their own political fragility might have determined this hesitation and, later on, their final choice in favour of France and its ideals, when France finally had to leave Algeria in 1962.

\section{A denominational pattern of integration.}

Being newly considered as a religious group, Jews (or "Israelites", as they were called since the nineteenth century) were required to integrate on the basis of a "denominational pattern". The Jewish global identity - associated with the pre-modern conception of a "nation" - was transformed into a religion which implied an individual adhesion to a faith (beliefs) and to practices. Based on a distinction between religious and civil rules, the Jewish practice thus constituted just one sphere of Jewish life, organized within a separate institution, the "Consistory", with its two heads: a Chief Rabbi for the spiritual matters and a President for the administrative management. A third feature may be added to this picture: toward the end of the $19^{\text {th }}$ century, when the "social utility" of religion was questioned and an autonomous secularised morality was independently elaborated ("morale laïque"), religion was more and

\footnotetext{
${ }^{5}$ The abrogation of the Crémieux Decree was maintained until 1943, one year after the Allies arrival in North Africa. See Weil (2004, chap. « Les crises ethniques de la nationalité française »).

${ }^{6}$ On this complex history, see Benjamin Stora (2006).
} 
more supposed to be confined to the private sphere. This meant restrictions on religion in the public sphere and on religious interference in political life, although no absolute legal prohibition existed. This denominational pattern can therefore be seen as consistent with the "Jacobin model" which dictates that the only identity allowed to be asserted in the public sphere by individuals or groups is the national one. Religious affiliation or regional belonging are considered thus as "secondary" identities, not at all relevant in the realm of political life. This ideological hierarchy is the basis of the individualistic principle of the French Republic, where no communitarian body can interfere between the State and the individual ${ }^{7}$.

\section{Accepting Diversity. Changes in French Political Tradition and within the Jewish}

\section{Community after World War II}

As previously mentioned, a Jewish cultural revival spread in France in the 1920's, in the aftermath of the Dreyfus Affair, encouraged by the strong Jewish identity of East-european immigrants. This "Réveil Juif" - note the return to the adjective "Juif" as a source of pride flourished essentially in the literary world, the press and youth movements. The support of some writers or leftist leaders for Zionism was another expression of this new Jewish pride. By supporting the cause of a "homeland" for their persecuted brothers, these French Jews tried to carve out a secular, left-wing Jewish identity in France, without giving it a Jewishnational expression within the French political sphere. They linked their pro-Zionist attitude

\footnotetext{
${ }^{7}$ The case of the Alliance Israelite Universelle may appear as contrary to this model. Founded in 1860 by Jewish scholars and intellectuals in order to defend their "brothers" persecuted in Russia and the Middle East, this organization intervened on the international scene. As such, it has been analyzed by Graetz (1996) as a renewed expression of Jewish peoplehood, a "proto-Zionism". But this political activism intended also to promote the French model of emancipation and its universalistic culture outside of France, especially among the Jews. By doing so, it also supported France's interests in colonial or protected countries. This ideological synthesis between French patriotism and Jewish engagement is known as "Franco-Judaism".
} 
with a strong sense of belonging to France ${ }^{8}$. Indeed this French-Jewish revival, which also comprised a blossoming of Jewish associative life, was forced later on to focus on the renewed battle against Anti-Semitism during the 1930s and the Vichy Regime. However, the existence of numerous secular Jewish associations may be seen as a quasi-political background that would favour later on a first shift toward institutional and political changes within the Jewish community.

First steps toward changes within the Jewish Community.

Although reintegration of the Jews into post-war French society took place along the former denominational pattern, a first and limited shift from this denominational pattern occurred on the institutional level, with the constitution in 1943 (officially in 1944) of a Jewish political body, a federation of all Jewish organisations including the Consistory, the Representative Council of Jews in France (in French, CRIF) ${ }^{9}$.

Why a "limited" shift ? Because it was decided that the chairman of the CRIF would be, by right, the President of the Consistory. Thus, the religious body formally remained the chief umbrella of French Jews, preserving a religious definition of Jewish identity and the centrality (although not the monopoly) of the Consistory as its representative institution. The CRIF was devoted to settling claims relating to confiscated property and to fighting Anti-Semitism, but its influence was in fact very limited until the 1970s.

Another new secular institution was created in 1949, the Fonds Social Juif Unifié (FSJU), which was devoted to social and cultural work among the Jews. It would increasingly have more and more impact on Jewish cultural life, as it coordinated and fund-raised in order to create several "Jewish Community Centers", based on a north-American model, where secular cultural and political activities became prevalent.

\footnotetext{
${ }^{8}$ On this period, see Charbit (2005) and Malinovich (2008).

9 The first full name of the CRIF was "Conseil Représentatif des Israélites de France" but immigrant organisations pushed to change it into "Jews of France', while keeping the same abbreviation. It became hereafter the "Conseil Représentatif des Institutions juives de France".
} 
During the 1950s and the 1960s, intellectual and demographic factors also laid the groundwork for a larger shift from the denominational pattern. The so-called "Ecole d'Orsay", a sort of Jewish-learning center functioning as a community headed by a charismatic leader (Léon Askenazi) was founded in 1947 by the leaders of a the Jewish Scouting movement (Eclaireurs Israélites ). Actually this Ecole would function, during its 20year life-span, as a training ground for many future institutional leaders. In addition to this informal "school", a Jewish intellectual revitalization would also develop around the figures of the philosopher Emmanuel Levinas and other Jewish thinkers (such as André Néher), who have been organizing annual meetings of French-speaking Jewish intellectuals since $1957^{10}$. On the demographic level, the arrival after Algerian independence of close to 200.000 North African Jews involved a profound transformation of the Jewish community, whose population doubled while the re-building of many local communities implied a new Jewish visibility in French society. Thus, the coming of these "Sephardic" Jews constitutes only one of the factors explaining for the Jewish revival of the 1970s, and not the sole one as it is commonly thought. Furthermore, it may be noted that a similar revival occurred during the same period in other countries (England, United States) where Sephardic Jews were not present.

\section{The Jewish revival of the 1970s: a shift from the denominational pattern}

The shift from the denominational pattern which took place in the 1970s can be illustrated by several phenomena, both political ones (public expressions of solidarity with Israel after the Six-Day War, fight against the deny of the Jewish Genocide) or cultural ones (Festivals of Jewish and Israeli cultures, new interest in Jewish History and folklore, the development of Jewish studies in universities and of a publishing sector), as well as new religious public expressions of Orthodox groups ${ }^{11}$.

\footnotetext{
${ }^{10}$ Colloque des Intellectuels juifs de langue française.

${ }^{11}$ For a precise description of this many-sided revival and its historical background, see Cohen (1993 and 2000$)$.
} 
These processes can be synthesized into three main features, still relevant today. Firstly, Jewish identity is no longer exclusively religious, but rather openly cultural and/or political as well. One may notice here the diversity and the complexity of this identity assessment: solidarity with Israel is not exclusive of a strong defence of a diasporic existence and culture; secular involvement is not contradictory to some religious practice, sometimes deliberately adopted in a selective and secular way. Secondly, although Jews are officially considered as a religious group represented by the Consistory, "Jewish interests" in other domains than religious affairs are de facto recognized, related to two other institutions. Firstly the CRIF, whose autonomous political role was affirmed with its institutional reorganization in 1977 and 1981, which submitted the position of chair to an election by the federated associations, taking it over from the President of the Consistory. This political role grew when the first elected President, Théo Klein, instituted an annual "CRIF Dinner" in 1985, regularly inviting the Prime Minister of the standing Government ${ }^{12}$. In addition to this political body, the FSJU informally took the place of a cultural representative institution vis-à-vis public authorities (in the schooling domain, for instance, although the FSJU is not the main founder of the numerous schools networks). Finally if the Consistory, as the mainstream religious institution, still includes the majority of Jews in France, it is now challenged by other religious groups, both orthodox and reform. Consequently, although it remains the official religious partner institution, other religious bodies do have their own contacts with French political authorities.

A plurality of Jewish identity models, a plurality of Jewish representative institutions and a plurality of religious institutions: these are the three-fold changes which are still in effect today within the organized Jewish community. This principle of separate organisations delineating three main domains (religion, culture and politics) is generally accepted - in spite

\footnotetext{
${ }^{12}$ Among other factors of this growing political influence of the CRIF, one can evoke the involvement of Théo Klein in the resolution of the "Auschwitz Carmel" affair (1985-87) when Catholic women wanted to maintain their Carmel Monastery inside the Auschwitz Campus. Good relationship with religious leaders of the Catholic Churches in France and Poland helped to resolve this problem. See Ghiles-Meilhac (2007).
} 
of a new competition for Jewish leadership which has recently developed, as we shall see hereafter - and can be said to express the secularization of the whole of Jewish community life, as well as its diversity. These profound changes in organised Jewish life couldn't have occurred without a simultaneous change within French society and French political tradition.

\section{Changes within French society and French political tradition}

Many pragmatic moves toward an enlarged religious pluralism can be noticed before and after World War II, with administrative arrangements facilitating religious practices for some minorities $^{13}$. This was followed, as in other Western societies in the $1960 \mathrm{~s}$, by a deep cultural shift toward cultural diversity. Critics of the "cultural uniformity" of the "Jacobin model" originated in regionalist movements. In addition, an individualistic morality developed with the refusal of all forms of authority (in family or at school). Secularization continued, as Catholic norms were increasingly dismissed in the domains of family and sexual life (laws establishing equality between men and women, permitting contraception, abortion). Diversity became a value in itself, as formulated later on by the slogan "the right to difference".

These changes in French political tradition toward public affirmation of minorities allowed Jews to adopt a global conception of their identity, going beyond the previous denominational pattern for defining their place in French society. One can speak also of an "ethnic" model.

\section{Debating Multiculturalism. From the 1980s to the 2000s: toward a fear of social}

\section{fragmentation}

In the last decades of the twentieth century, two major changes led to a new perception of diversity as a potential risk for social cohesion: the presence of Muslims in France - and in Western societies in general - and globalization, which implies bolstered exchanges between "North" and "South". This multi-faceted turmoil - labour migrations, de-locating business enterprises, mass tourism, new technology and mass-communication, etc. - involves a new

\footnotetext{
${ }^{13}$ See in particular Messner (1993), Basdevant-Gaudemet (1996) and the co-called "Machelon Report" (2006).
} 
intertwining of secularized and non-secularized societies, as well as religious and political issues. Furthermore, formerly colonized populations became a constituting part of the nationstates that once ruled over them. This radical mutation implies another confusion, a sort of historical backlash, with the upsurge of memories of these "others" within the normative national narrative. As a consequence, the place of the Jews in France has been somehow destabilised. This is not to say that their integration is questioned, but rather that they are no longer the historic "other" of a Christian majority society.

\section{Religion and Politics intertwined on the National and the International scenes}

Settlement of Arab migrant families in French society and persisting discriminations against them led to their new perception as a religious group, but also to a "politicization" of Islam, reinforced by the emergence of a radical political Islam on the international scene. While such a politicization can be seen also among the Jews, it is far from being a similar process.

Toward a denominational pattern vs politicization of Islam With the settlement of Arab migrants' families during the 1970's, diversity was first conceived along a cultural pattern, associated with Left ideals (François Mitterrand was elected as President in 1981). The slogan of "the right to difference" was adopted by young Arabs during their first "March for Equality" in 1983 and by the anti-Racist association "SOS-Racisme" which was created in 1984 by Jews and Maghrebians together, many of them being socialist supporters. But persisting discriminations against Maghrebians (notably in the socio-economic and housing fields), as well as police brutality, which have led to recurrent urban riots since the summer 1981, cast doubts on this "right", which gradually gave way to another slogan: the "right to similarity" - e.g. invisible identity in the public sphere.

This first move back to the "Republican model" was associated with a new political objective: the building up of a "French Islam". With the first attempt to organize Islam into an institutional religious frame in 1990 by the Socialist Pierre Joxe, religious affiliation began to 
appear as a more legitimate collective identity than ethnicity ${ }^{14}$. A denominational pattern was thus proposed to the immigrants and their children, whereas it was perceived at that time as old-fashioned among the Jews. But those "Muslims" who were secularized didn't want to be ascribed a religious identity ${ }^{15}$, and some voices asked publicly if religion was a suitable frame for "Muslims". Referring to the Jewish CRIF and the existence of secular Jews, they created secular Muslim associations, thus claiming another ground of legitimacy for their representation.

As a matter of fact, the Islamic reference became for some a means of personal identity searching (several leaders of the "March for Equality" became religious activists as early as 1985) and newly created Muslim associations took over the former fight against discrimination. Besides, the French government didn't follow through on its own call to create a "French Islam" and often turned to foreign Muslim Governments (specially in North Africa) in order to get control over these new activists. Political interests thus interfered all along the process of creation of the French Islam "representative" body, which was finally achieved in 2003, under pressure from the then Minister of the Interior, Nicolas Sarkozy ${ }^{16}$. This multiple process of the "politicization of Islam" increased with the growth of the extreme-right party (National Front) during the 1980s, which denounced the alleged danger of Islam for French National identity. The theme of immigration still continues to be a political issue connected to Islam on both the left and right sides of the French political spectrum, with political leaders pandering to a "Muslim vote".

\footnotetext{
${ }^{14}$ Joxe created the "CORIF" (Organisational and Reflexive Council for Islam in France); it was just one year after the first "headscarf affair" in 1989.

${ }^{15}$ See the survey conducted by Brouard and Tiberj (2006).

${ }^{16}$ Sarkozy insisted that the first Chairman of the French Council for Muslim Cult (CFCM) would be the Rector of the French-Algerian Mosque of Paris, Dalil Boubakeur, for political reasons (links with the Algerian government) as well as for religious motives: Boubakeur is supposed to belong to a "reform" wing of Islam.
} 
we know, Islamic Parties succeeded in conquering state power in Iran (1978) as well as in Afghanistan at the same time. This gradually had political consequences within European societies. The beginnings of international Islamic terrorism showed the reality of a political, violent Islam, which was "confirmed" by the Rushdie Affair (1988) and later on by Al Qaeda terrorism. The Palestinian revolts against the Israeli occupation also expressed themselves more and more in religious ways. These various religious-political causes have been somehow "reunified" by Al Qaeda leaders into an Islamic struggle against "the Western world", gaining here and there supporters within European societies ${ }^{17}$.

If Muslim Diaspora communities may help develop a new sense of trans-national solidarity - different from the previous national belonging of the first migrants - they can also give room to Islamic radical tendencies, even if this constitutes a minority phenomenon. In France, young Muslim generations aspire to their incorporation into French society, but they are sometimes regarded with a fair amount of suspicion. Although the majority of them are secularised and individually integrated, the religious activism of some Islamic organisations or leaders among them triggers the fear of an ambivalent trans-national (global) community: is the "Umah" a spiritual "community of believers" or a political trans-national group which opposes loyalty to the French nation.

Within the French Jewish Community: the impact of Israeli policy and religious radicalization During the 1970 s and the 1980 s, similar fundamentalist tendencies appeared in the Jewish realm. But it was not on the same scale and it did not endanger the democratic State of Israel, nor the integration of French Jews. Furthermore, these evolutions involved neither the emergence of an international Jewish terrorism nor a threat towards West European countries.

\footnotetext{
${ }^{17}$ The Fall of the Berlin Wall, in 1989 ended a world polarization against Communist ideology, but it also opened the way to other expressions of ideological confrontations, in religious or "civilization" terms.
} 
The recovering of "sacred" territories by Israel during the Six-Day war (1967) favoured there a religious revival focused on the new political-religious slogan of "Great Israel". A religious Zionism linked to right-wing parties gained more and more influence in the governmental spheres (the first victory of the Right party Likud occurred in 1977), enhancing the religious legitimacy of settlement in the occupied territories. These developments led to increasing conflicts in Israel, concerning these settlements as well as the justification of military operations since the Lebanon war in 1982. They also echoed among French Jews. They actually became a matter of controversy within and outside the Jewish Community. Hence Jewish solidarity with Israel, which was previously consensual among Jews and encouraged by sympathy from the larger French society, became more complex and problematic. The political role of the CRIF grew and appeared to some as a pro-Israeli lobby.

Toward the end of the 1980s, changes occurred too within the French religious sphere. A new Chief Rabbi who was close to ultra-orthodox circles was elected in 1987 (in function in 1988). He began to integrate some of their members into the Consistory or to associate them with its public actions. This religious radicalization, which enhanced the "sectarian" (religiously exclusive) character of the Consistory, provoked notably the surge of new "secular Jews" organizations (1989 and later on). One may analyse this polarization as a classical battle between anti-clerical movements and radical religious groups. But it also shows a sort of politicization of the French Jewish realm, since the Chief Rabbi is now competing with the CRIF over the Jewish leadership. Hence, while the previous distribution of roles between the three Jewish institutions didn't give a prominent place to any and somehow restrained the political implication of the CRIF, the competition now enhances the perception of a strong collective Jewish entity whose nature may be either political or religious ${ }^{18}$. This may be analysed as a political step toward ethnicity, beyond the former

\footnotetext{
${ }^{18}$ The competition has grown over and over during the last years, leading the CRIF to engage in religious matters (encounters with Muslims, Catholics and Buddhists), while the Chief Rabbi organizes meetings and popular trips to Israel to support its settlement policy in the occupied territories.
} 
cultural or religious activism, at a distance from the denominational pattern and the previous "Franco-Judaism".

The headscarf affairs: multiculturalism against laicité ? The first headscarf affair occurred in October 1989 and sparked several questions. An "old" debate first concerned two principles both associated with French laïcité but which suddenly appeared as contradictory: guarantee for individual religious freedom or "religious neutrality" of the public sphere imposing "invisible" identities? When this later principle was globally consensual, no major claim went to contradict it in State schools (all the more as religious expressions did fade away with the general process of secularization). But since the $1970 \mathrm{~s}$, individual rights gained supporters in many domains, including free expression of pupils at school. For those who were more accustomed to political youth movements, the upsurge of religious expression at school raised surprise and opposing positions, either in favour of a complete freedom (even if it was contrary to their own secular option) or in favour of a strict laïcité - which appeared then for the first time as opposed to individual rights. When Prime Minister Jospin asked the State Council for its opinion on this affair, it responded by affirming the principle of free religious expression for pupils but not for teachers as Civil servants, thus adding to the confusion

A second and new debate was also triggered, which concerned the issue of emancipation. It was framed either in gender terms - does the headscarf mean a real free choice or inferiority of women? - or in more general terms: how can individual choice lead to religious involvement, contradicting our modernization scheme based on the principle of progressive liberation from religious values and norms? If former identity movements were based on individual choice against "Jacobin uniformity", this new form of "differentialism" based on inherited identities didn't appear clearly as a "progressive" step, since it seemed to encourage "archaic" and holistic identities. In other terms, the question was: in the name of multiculturalism, would it be possible to imagine different ways of emancipation? This 
disturbing question led some activists of laïcité to oppose to multiculturalism, when others rather highlighted the complex processes of individualism in different cultures or societies ${ }^{19}$.

The following headscarf's affairs were analysed also as a mixed political-religious issue. They were linked by public opinion (with reason or not) to international Islamic political movements which tried to reinstall (or reinforce) the religious law (the Sharia) in Muslim countries. Then the renewed question of laicité guaranteeing individual religious freedom came to the fore, as opposed to hypothetical pressures from religious-political groups on Muslim individuals and on French society. Although this reality hasn't been statistically studied of yet, the supposed growing influence of these international pressures added motives for the reassessing of the "principles of laïcité".

\section{A growing ethnic perception of French society and the return to a restricted laïcité}

The already conflicted international scene went through a dramatic worsening at the beginning of the new millennium, with political repercussions in France. The renewed Palestinian-Israeli conflict (the "second Intifada", since autumn 2000) and the Durban Conference in September 2001, where Arab countries concentrated their harsh critics on Israel, immediately followed by the terrorist attack against the World Trade Center on 9/11, crystallized previous oppositions between French Jews and Muslims. Anti-Semitic slogans were heard during the pro-Palestinian demonstrations, physical attacks increased against the Jews or Jewish buildings, at a point that a fear of social fragmentation became a dramatic issue of concern. Added to the visible contradictions of multiculturalism (also related to the new debates which arose in England after the July 2005 terrorist attack), it called into question the previous positive French attitude toward the celebration of "diversity".

Furthermore, while the incorporation of memory of the Holocaust within French national memory was seen as a positive way to think anew a contested period of France

\footnotetext{
${ }^{19}$ These activists were also close to post-colonial perspectives, when refusing the exclusive model of Western modernization.
} 
History $^{20}$, new claims of Muslims activists about reconsidering the colonial domination sounded like an accusation against France as a whole and provoked strong oppositions. As anti-Muslims discriminations continued, the idea of "privileges" attributed to the Jews by French society and public authorities became more or less wide-spread among Muslims milieus. Could we speak of "jealousy" toward "well integrated" and "successful" people? ${ }^{21}$ An old, and probably not conscious, resentment may have nourished this jealousy with regard to the privileged status Jews acquired in Algeria during the colonial period with the Crémieux Decree. In this climate, while many Jews thought a new Anti-Semitism has emerged (a “judeophobia", according to some scientists) $)^{22}$, Muslims spoke of "islamophobia" to qualify their own numerous discriminations. A competition between victims thus developed and worsened with the claim about reconsideration of Black slaves' traffic by European countries $^{23}$.

The ethnic perception of French society thus increased and was even implicitly confirmed by positive initiatives such as the creation, in 2004 by a Rabbi, of the JewishMuslim Friendship Association and its circulating "Fraternity Bus". The positive attitude

\footnotetext{
${ }^{20}$ It was in 1993 that President Mitterrand decided to establish a new national celebration related to the memory of the French participation of the Vichy Regime in the Jewish Genocide; President Chirac went further in 1995 when he officially recognized the "collective fault" of the French State.

${ }^{21}$ The murder of the young Jew Ilan Halimi by a "barbarian gang", in 2006, revealed such a jealousy toward "rich people", as it was written in the letters of the gang.

${ }^{22}$ Taguieff (2002) invented the term "judeophobia" to designate the way Anti-Semitism was now hiding behind "anti-Zionism" and critics against Israel. According to scientific surveys, most of the attacks were attributed to Arabs/Muslims, but they were not necessarily analysed as Anti-Semitism. Due to their close relationship to the periods of Israeli assaults against Palestinians, some scientists like Mayer (2005) thought that this motive would disappear with the end (or the weakening) of the conflict; others like Wieviorka (2005) insisted on the economic and social frustrations of non integrated young people. Laurence and Vaisse (2007, chap. 9) give a good synthesis of these studies, concluding however on the persistence of a "structural" Anti-Semitism.

${ }^{23}$ Chaumont (1997) was the first who spoke of a "competition between victims".
} 
toward "diversity" could remain the slogan for some political steps (for instance the creation of the French Council for Muslim Cult in summer 2003), or the true preoccupation of new managers, but it also had to face strong oppositions to any assessment of "ethnic" groups within the national frame.

As a matter of fact, religious signs and especially the headscarf became the core of the ideological battle against these "ethnic" quarrels. New headscarves' affairs led the French Government to create in July 2003 the "Stasi Committee on Laïcité", which published a Report with 25 proposals at the end of the year ${ }^{24}$. But none of them was adopted except one: a new law forbidding any "conspicuous" religious sign at school (March 2004), which is often seen as having the unique purpose to suppress the "Islamic veil".

On the field, the interpretations of this law now go far beyond its strict expression. The ban on the headscarf in school is often taken as a general ban, with several cases of women excluded from a City Hall during a wedding celebration or from places of work (private and public). Other cases of inequality regarding the Muslims have been recently noticed: while Mayors frequently agree to rent municipal land cheaply to religious groups (Catholics, Protestants, Jews and even Muslims) who wish to build a place of worship, members of a nationalist party (a dissident one from the National Front) locally challenged the Muslims' right to benefit from this same advantage in three places (Marseille, Roubaix and Montreuil); the judicial contest was grounded, it was said, on a strict interpretation of the Separation Law of 1905 forbidding any financial support to religious groups from public authorities ${ }^{25}$.

Other recent cases put into question the financial state support previously given for the social activities of religious groups (Youth Camps of Catholics, Protestants as well as of Muslims and Jews); this led the French Protestant Federation to address a protest, in 2006, to

\footnotetext{
${ }^{24}$ Commission Stasi (2003)

${ }^{25}$ In one case (Marseille), the Mayor and the Muslim association negotiated a new price; in the two other cases (Montreuil, Roubaix), the Muslim Associations appealed against the judicial contest; the cases are not over.
} 
the new French Authority officially established for fighting against discrimination (Halde) ${ }^{26}$. Concerning particularly the Jews, previous individual arrangements facilitating religious practice are called into question (the wearing of the kippa at school, permission of being absent on Saturday). By making this parallel with Muslims' demands, it is implicitly assumed that Jews' requests, which were previously granted on the basis of individual practical accommodation, now could ultimately be also a threat to Republican values as well as to national unity.

The former processes of enlargement of the scope of pluralism are thus being put into question, in contradiction with the liberal understanding of secularism which was practiced since 1905 till the 1980's decade. Due to its long and rich history, French secularism is a complex and multiple site of memory. When facing radical changes regarding the nature of the public space, in the context of international political tensions, some activists of laïcite tend to remember the "old battles" of the Republican Regime against the Catholic Church and to call for a new vigilance toward all religious requests.

\section{Conclusions}

From religious pluralism to cultural diversity: France facing the fear of social fragmentation The historical overview first showed us the progressive enlargement of religious pluralism to the sole non-Christian religion which was present in France in the $19^{\text {th }}$ century, Judaism. But the non-respect of this principle concerning the Muslims in colonial Algeria demonstrated the reluctance of a culturally (religiously) Christian France, when facing "others" who were demographically in a position to oppose its colonial power if they had been given full citizenship. Algerian Jews (between 15.000 and 20.000 people in 1831), by contrast, were given the same political status as French Jews, namely that of full-fledged French citizens. However, the two major crises which endangered their place within the national frame or even

\footnotetext{
${ }^{26}$ To this date, no proper response has been given.
} 
excluded them from it for several years (the Dreyfus Affair and the Vichy Regime) showed the persisting conception of a Catholic-French identity. When post-war France re-integrated them, the explicit acceptance of secularism by the Catholic Church did reassure the Republican regime, which began to enlarge the principle of religious pluralism and to include other minority groups. Later on, the continuing process of secularization, as well as economic welfare and moral individualism, allowed a new openness of French society to cultural diversity.

But persistent discrimination against Arab-Muslims immigrants cast doubt on the efficiency of the "right to difference" model as a means to integration. The wish to return to the "Republican model" and to consider the immigrants and their children as "Muslims", along the old denominational pattern, was then reinforced in public opinion by new factors: the upsurge of a political Islam on both the international and national scenes, as well as the growing impact of religious-political conflicts in the Middle East on relationships between French Muslims and Jews. The fear of social fragmentation along "ethnic" or religious differences has now resulted in a new debate on laïcité as opposed to multiculturalism, a term which has become a synonym for "separatism".

\section{Multiculturalism in a global world vs Secularization in "old" national identities}

Secularization implies not only the limitation of religion to one specific sphere of social reality and the decline of religious practice, but also the possible transformation of some religious symbols and celebrations into secular festivals or patrimonial signs. These secularization processes are now questioned by globalization and by the rise of a political radical Islam.

With globalization, Western societies develop tight relations with non-secularized societies, from where immigrants may either partake in the secularization process of their new national frame (this seems to be the case for the majority of them), or not. Thus, secularized symbols like the Christmas tree, for example, might be now contested as "non neutral" and related to their Christian background, as it is the case in several Western countries (France, 
Italy, England, United-States, etc.). In response, public opinion may reconsider this symbol either as part of a common collective identity - and defend its use - or as the survival of a religious sign which must be removed in order not to offend the new comers - this has been done, for example, by turning "Merry Christmas" wishes into "Happy Holidays".

Thus, "religious" signs may be used by Western societies as part of their cultural background, defining a more or less open national identity (as well as on the local or the European level), and thus including or conflicting the immigrants' cultures. This possibility of conflict may be in turn exploited by political radical Islam, specially (but not only) when the integration of Muslim immigrants is difficult or even fails (because of discrimination, economic crisis, or the weakened integration capacities of the State). Confronting this proposed alternate Muslim trans-national identity, the debate on "religious symbols" has turned into a debate on "national identity". Global religious identities have become a possible competing frame to that of the National States.

In a global world, multiculturalism destabilizes "old" national identities. It questions the supposed neutrality of the modern liberal States which were built up in the Western world especially in France where the political model of a Nation built up on civic bounds "covered" the social reality of a cultural Catholic majority. Thus, if we pretend to preserve the existence of a national frame, how can we elaborate new cultural "compromises" in the context of a conflicted global world? How can Democracies continue to maintain and manage their existing pluralism - which includes the right of every individual to exit from his primary group - against extremists' attacks and radical identities? 


\section{BIBLIOGRAPHY}

Albert-Cohen P. (1977), The modernization of French Jewry : Consistory and Community in the Nineteenth-Century, Waltham, Mass : Brandeis Univsersity Press.

Basdevant-Gaudemet B. (1996), 'Le Statut juridique de l'islam en France', Revue de Droit Public, 1996, p. 355-385.

Baubérot J. (2000), Histoire de la laïcité en France, Paris, PUF, (4 ${ }^{\text {th }}$ reissue, 2007).

Berkovitz J.R. (1989), The Shaping of Jewish Identity in Nineteenth-Century France, Detroit, Wayne University Press.

BIRNBAUM P. (1992), Les Fous de la République. Histoire politique des Juifs d'Etat, de Gambetta à Vichy, Paris, Fayard (The Jews of the Republic : A Political History of State Jews in France from Gambetta to Vichy, Standford, Standford University Press, 1996).

Brouard S. and Tiberj V. (2006), Français comme les autres? Enquête sur les citoyens d'origine maghrébine, africaine et turque, Paris, Presses de Sciences Po.

Charbit D. (2005), 'Déclinaisons du franco-judaïsme', in David BIALE (ed.), Les Cultures des Juifs. Une nouvelle histoire, Paris, éditions de l'Eclat, 2006, pp. 1003-1042.

Chaumont J-M. (1997), La Concurrence des victimes : génocide, identité, reconnaissance, Paris, La Découverte.

Cohen M. (1993) : «Les Juifs de France. Affirmations identitaires et évolution du modèle d'intégration », Le Débat, nº75, mai-août, pp. 101-115.

--- (2000): «Les Juifs de France. Modernité et identité »,Vingtième Siècle. Revue d'Histoire, $\mathrm{n}^{\circ} 66$, avril-juin.

Commission Stasi (2003), Commission de Réflexion sur l'Application du Principe de Laïcité dans la République. Rapport au Président de la République, 11 Décembre 2003.

http://www.ladocumentationfrancaise.fr/cgi-bin/brp/telestats.cgi?brpref=034000725\&brpfile=0000.pdf

Ghiles-Meilhac S. (2007), La Politique étrangère du Conseil Représentatif des Institutions Juives de France, La communauté juive organisée : une force diplomatique ?, Mémoire de Master 2 d'Histoire, EHESS. 
Graetz M. (1996), The Jews in Nineteenth-Century France: From the French Revolution to the Alliance Israelite Universelle, Stanford, Stanford University Press.

Hermon-Belot R. (1999). L'Emancipation des juifs en France, Paris, PUF.

Hyman P. (1998), The Jews of Modern France, Berkeley, University of California Press.

Laurence J. and Vaïsse J. (2007), Intégrer l'Islam. La France et ses musulmans : enjeux et réussites, Paris, Odile Jacob.

Malinovich N. (2008), French and Jewish. Culture and the Politics of Identity in Early Twentieth Century France, Oxford-Portland, The Littman Library of Jewish Civilization.

Mayer N. (2005): "Les opinions antisémites en France après la Seconde Intifada", Revue internationale et stratégique, nº58 (été 2005).

Messner F. (1993). « Laïcité imaginée, laïcité juridique. Les évolutions du régime des cultes en France », Le Débat, nº77, nov-déc., pp.88-94.

Machelon Report (2006). Commission de réflexion juridique sur les relations des cultes avec les pouvoirs publics, septembre.

Stora B. (2006), Les trois exils des Juifs d'Algérie, Paris, Stock.

Taguieff P-A. (2002), La Nouvelle judéophobie, Paris, Fayard-Mille et une nuits,

Weil P. (2004), Qu'est-ce qu'un Français? Paris, Grasset, Folio-Histoire, (1 $1^{\text {ère }}$ éd. 2002).

Wieviorka Michel (2005), La Tentation antisémite. Haine des Juifs dans la France d'aujourd'hui. Paris, Robert Laffont. 